\title{
ABDOMINNOSKROTAL HIIDROSEL
}

\author{
ABDOMINOSCROTAL HYDROCELE
}

\section{Aziz PEKER Ahmet ARIKAN}

SUMMAR'Y

Abdominoscrotal hydrocele is rarely encountered. A fifteen years old case which is overlooked during the first examination but diagnosed after recurrence is presented in this article.

(Key Words: Abdominal Wall, Mass, Scrotum)

\section{ÖZET}

Abdominoskrotal hidrosel ender görülür. Rutin bakıda gözden kaçan ancak nüks gelişmesinden sonra saptanan onbeş yaşında bir olgu sunulmuştur.

(Anahtar Kelimeler: Karın Duvarı, Kitle, Skrotum) 
Hidroselin genelde üç tipi vardır. En sık görülen birinci tip tunika vaginalisin skrotum içinde ve testis çevresinde sıvı ile dolmasıdır. Daha az görülen ikinci tip kistik kitlenin spermatik kordon çevresinde inguinal kanala doğru uzanması, üçüncü tip ise en az görülen, skrotal kistik kitlenin inguinal kanal içinden batına doğru uzanmasıdır. Buna abdominoskrotal hidrosel denilmektedir (1).

Abdominoskrotal hidrosel ilk kez 1834 yılinda Dupuytren tarafindan tanımlanmıştır. Yakın zamana dek 90'in üzerinde olgu bildirilmiştir (2). Çocuklarda daha az görülmektedir.

Hastalığın etiyolojisini Dupuytren, büyüyen hidroselin artan basıncının tunika vaginalisi inguinal kanala doğru itip, batın içine doğru genişlemesi şeklinde açıklamıştır (3). Olay ayrica "Laplace" yasasına da dayan-d1rılmıştır. Yani sekretuvar aktivitenin sürekliliği ile skrotum sıvısı kanala doğru itilir. Genişlemeyen, muskulofasial kılıf ile çevrili inguinal kanalda basınç değişmeden kalır ve olduğu gibi inguinal kanalın iç ağzına iletilir. Kese içi basınç, karın içi basıncı $4-6 \mathrm{~cm}$. $\mathrm{H}_{2} \mathrm{O}$ geçecek olursa abdominoskrotal hidrosel gelişmektedir (4). Başka bir görüşe göre; Procesus vaginalis inguinal kanalın iç ağzına yakın çok kısa oblitere olursa, skrotumda gelişen hidroselin karına doğru ilerlemesi kolay olmaktadir $(2,5)$.

\section{OLGU}

15 yaşındaki hasta üç yıldır var olan, son zamanlarda artan sol skrotum şişliği nedeni ile başvurdu. Doğum sonrası saptanan bilateral inguinal herniler 2 yaşında opere edilmiş. 12 yaşına dek yakınması olmayan hastanın bu dönemde kısa sürede gelişen sol skrotal şişliğine hidrosel tanısı konulmuş, tedavisi ertelenmiş. Bize geldiğinde sol skrotumda $10 \times 10 \mathrm{~cm}$. boyutlarında, oldukça gergin, inguinal kanalın dış ağzını tamamen kaplayan, transillüminasyon bakısı pozitif, hidrosel ile uyumlu bulgular saptand.

Fizik bakı ve laboratuvar tetkikleri özellik göstermeyen olguya bir özel hastanede skrotal insizyon ile Winkellman operasyonu uygulandı (15.2.1991). Testis normalden küçük bulundu. Intraoperatif, inguinal kanala doğru uzanan hidroselin üst sinırı palpe edilemedi, hidroselin geçirilen fıtık operasyonunun kanalın iç ağzında oluşturduğu yapışıklıklarda sonlandığı düşünüldü. Illk postoperatif devre komplikasyonsuz seyretti. Bir ay sonra ayn bulgularla nüks gelişti.

Bunun üzerine yapılan ultrasonografik bakıda skrotumdaki kistik kitlenin inguinal kanalı geçip, karına doğru uzandığı, mesanenin yanında yer aldığı görülddü. Böbreklerde obstrüktif patoloji saptanmadı. Alt batın bilgisayarlı tomografi tetkiki ile bu kistik kitlenin mesane ve periton içi organlar ile ilişkili olmadığı görüldü (Bilrad). Fizik bakıda hidroselin karın içi bölümü rektus kası altunda palpe edilememekteydi.

Hastanemize yatirlan (Karantina No: 9972) hastaya gerekli ön hazırlıklardan sonra suprapubik paramedian kesi ile girilip retroperitoneal yerleșmis, takriben $15 \times 15$ $\mathrm{cm}$. boyutlarındaki kistik kitle serbestleștirilip, inguinal kanalın iç ağzında eksize edildi. Skrotum içeriği boşaltılıp, skrotal bağlantı ağzı kapatıldı (2.7.1991). Daha önce skrotumda Winkellman operasyonu yapıldığı için buraya bir daha başka işlem uygulanmadi. Nüiksün nedeni olarak skrotumdaki rezorbsiyon yüzeyinin karın içindeki kist duvarının sekresyonuna yetmediği düşünüldü.

Post operatif devre komplikasyonsuz seyretti. Eksize edilen materyalin patolojik incelemesi hidrosel ile uyumlu sonuç verdi (Prot. No: 3303/91). 6 ay sonra daha küçük boyutlarda olmak üzere $(5 \times 5 \mathrm{~cm}$.) tekrar nüks hidrosel geliștiği gözlendi. Skrotumdaki sekretuvar yüzeyin (tunika vaginalis) daha geniş eksizyonu için operasyon planland 1.

\section{TARTIŞMA}

Hidrosel skrotum hastalıkları içinde en sık görülenlerinden olmasına karşın abdominoskrotal hidrosel enderdir. Bu olguda ol- 
duğu gibi daha önce inguinal kanalda bir operasyon geçirmiş ve alt karında palpabl bir kitle saptanamayan olgularda akla gelmesi zordur. Literatürde geniş hidrosel serileri içinde abdominoskrotal hidroselin görülme oranı $\% 0.2$ civarındadır $(1,6)$.

Tanıda ultrasonografi değerli ve kolay uygulanabilir bir yöntemdir. Ayrica üriner sistemdeki obstrüktif patolojiler bu yöntemle hemen saptanabilir.

Türkçe yayinlarda skrotumda ve alt karinda şişlikle kendini gösteren ve 5 litre kist sıvısı boşaltılan bir olgu (7) ile bilateral hidronefroz ile birlikte seyreden baskka bir abdominoskrotal hidrosel olgusu bildirilmiştir (8).

Tedavide paramedian alt karın yolu veya uzatilmiş inguinal kesi ile kist eksizyonları yanında tetrasiklin gibi sklerozan ilaçlar uygulanmaktadir $(6,7,9)$. Bu olguda skrotuma uygulanan Winkellman operasyonu yetersiz kalmıs, daha geniş bir tunika vaginalis eksizyon gereği doğmuştur.

Sonuç olarak inguinal kanalın diş ağzını kaplayan büyük hidrosellerde alt karında kitle palpe edilemese bile ultrasonografi ile kistik kitlenin sinurlarmın belirlenmesi gerektiği ve inguinal kanalda geçirilmis operasyon yapısıklıklarının abdominoskrotal hidroselin gelişmesini engelleyemediği söylenebilir.

\section{KAYNAKLAR}

1. Black RE, Cox JA, Han B, Babcock DS. Abdominoscrotal Hydrocele. Pediatrics 1981; 65: 420-2.

2. Sguire R, Gough DCS. Abdominoscrotal Hydrocele in infancy. Brit J Urol. 1988; 61:347-9.

3. Casulari E, Cacciasi A, Federici S. Abdominoscrotal Hydrocele in childhood. Case Report and Review of the Literature. Z Kindenchir. 1983; 38: 353-5.

4. Brodman HR, Brodman LE, Brodman RF. Etiology of abdominoscrotal hydrocele. Urology. 1977; 10: $564-5$.

5. Booth J. Abdominoscrotal Hydrocele. I Ped Surg. 1987; 22 (2): 177-8.

6. Tanga MR, Avaradi PR, Gandhi MG. Abdominoscrotal Hydrocele. Brit J Surg. 1973; 60: 834-6.

7. Çıkılı N, Kerimoğlu H. Abdominoskrotal Dev Hidrosel. Türk Üroloji Dergisi. 1982; 3: 179-82.
8. Kendi S, Akdaş A, Taşar Ç. Abdominoskrotal Hidrosel. Hacettepe Tup Cerrahi Built. 1977; 10 (1): 89-92.

9. Parekh G, Reinboth OP, Mishara. Abdominoscrotal hydrocele. Brit J Surg. 1975; 62: 629-32.

\section{Dergimize}

\section{ABONE OLDUNUZ MU ?}

\author{
Not: Abone formu \\ derginin sonundadır.
}

